\title{
Screening of Hemoglobin Disorders in Referral Cases to the Hospital's Laboratory in Northeast Iran
}

\author{
M. Reza KERAMATI ${ }^{1}$, M. Hadi SADEGHIAN ${ }^{2}$, Hosein AYATOLLAHI ${ }^{2}$, Yousef YOUNES $^{3}$ \\ ${ }^{1}$ Mashhad University of Medical Sciences, Faculty of Medicine, Imam Reza Hospital, Neonatal Research Center \\ ${ }^{2}$ Mashhad University of Medical Sciences, Faculty of Medicine, Ghaem Hospital, Cancer Molecular Pathology Research \\ Center \\ ${ }^{3}$ Mashhad University of Medical Sciences, Faculty of Medicine, Imam Reza Hospital, Nuclear Medicine Research Center, \\ Mashad, IRAN
}

\begin{abstract}
Determining the frequencies of hemoglobin disorders in referral cases to the hospital's laboratory for designing the best program for prevention, early diagnosis and treatment of these disorders. Hemoglobin electrophoresis and CBC were performed on 6033 cases referred to Imam Reza hospital, Mashhad, Iran from 2004 to 2009. Normal and abnormal electrophoretic patterns were identified in $77.55 \%$ (4679 cases) and $22.44 \%$ (1354 cases), respectively. The most common hemoglobin disorders, in order of frequency, were B-thalassemia minor (19.44\%), Hb D (1.63\%), Hb S (0.38\%), thalassemia intermedia to major $(0.24 \%)$, thalassemia major $(0.23 \%)$, $\delta \beta^{0}$-thalassemia (heterozygous) $(0.18 \%)$, hereditary persistence of fetal hemoglobin (heterozygous) $(0.1 \%), \mathrm{Hb} \mathrm{H}(0.1 \%), \mathrm{Hb} \mathrm{C}, \mathrm{E}$ or $\mathrm{O}(0.07 \%)$, HbLepor (heterozygous) $(0.03 \%), \mathrm{Hb} \mathrm{D} / \mathrm{B}^{+}$-thalassemia $(0.02 \%)$ and $\mathrm{Hb} \mathrm{S} / \mathrm{B}^{+}$-thalassemia $(0.02 \%)$.

Based on our study hemoglobin disorders are a common problem in this region as the abnormal results in electrophoresis were observed in the $22.44 \%$ of individuals. These results show the importance of a premarital screening program for hemoglobin disorders in this geographic area.
\end{abstract}

Keywords: Hemoglobin disorders, Thalassemia, Hemoglobinopathy, Hemoglobin D, Hemoglobin S, Hemoglobin H

\section{ÖZET}

Kuzeydoğu İran da Hastane Laboratuvarına Gönderilen Hastalarda Hemoglobin Bozukluklarının Taranması

Bu çalışmanın amacı hastane laboratuvarına sevk edilen hastalarda hemoglobin bozukluklarının sıklı̆ının belirlenerek, önleme, erken tanı, ve tedavi programlarının hazırlanmasında rehber oluşturmasıdır. İmam Rıza hastanesi, Meşhed, İran'da 2004-2009 yılları arasında, hemoglobin elektroforezi ve tam kan sayımııı yapıldığı 6033 olgu değerlendirmeye alındı. Normal ve anormal elektroforez modelleri sırasıyla \%77.55 (4679 olgu) ve \%22.44 (1.354 olgu), tespit edilmiştir. En yaygın hemoglobin bozuklukları, sıklık sırasına göre, B-talasemi minör (\%19.44), Hb D (1.63\%), Hb S (0.38\%), majör talasemi intermedia-majör (\%0.24), talasemi majör (\%0.23), $\delta \beta^{0}$-talasemi (heterozigot) (\%0.18), kalitsal kalıc fetal hemoglobin (heterozigot) $(\% 0.1), \mathrm{Hb} \mathrm{H}(\% 0.1), \mathrm{Hb} \mathrm{C}$, E veya O (0.07\%), HbLe-

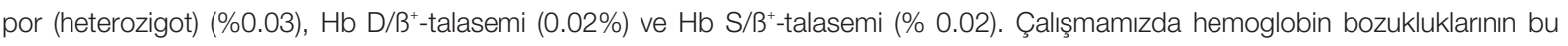
bölgede önemli bir problem olduğu görülmüştür. Elektroforez sonuçlarına göre anormal ob- sonuçlar bireylerin $22.44 \%$ de izlenmiştir. Bu sonuçlar bu coğrafi alanda hemoglobin bozuklukları için evlilik öncesi tarama programının önemini göstermektedir.

Anahtar Kelimeler: Hemoglobin bozuklukları, Talasemi, Hemoglobinopati, hemoglobin D, Hemoglobin S, Hemoglobin H 


\section{INTRODUCTION}

Hemoglobin disorders are a worldwide problem. They have spread during migration from high prevalence areas such as the Mediterranean, Africa and Asia to low prevalence areas such as Europe and America. Although control programs have limited affected newborns and increased survival of the patients, these disorders are still one of the most common genetic problems even in the developed countries. ${ }^{1}$ There are two main types of hemoglobin disorders: thalassemias with defects in the synthesis of a hemoglobin chain and hemoglobinopathies with defects in its structure. ${ }^{2}$ Thalassemia carrier rate in Iran, located in the middle of the so-called thalassemia belt, is high. ${ }^{3}$ Some hemogllobinopathies particularly Hemoglobin D, named hemoglobin D Iran, and hemoglobin $S$ have also high frequency in this region. ${ }^{4}$ In the recent decades, due to administration of a preventing national program for thalassemia, including premarital screening, prenatal diagnosis and therapeutic abortions, the prevalence of thalassemias have decreased to some extent, but still these disorders are a serious health problem. ${ }^{3}$

Characterizing the frequencies of hemoglobin disorders in different geographic areas helps the health care providers to design the best program for prevention, early diagnosis and treatment of these disorders particularly appropriate for specific ethnic groups.

\section{MATERIAL AND METHODS}

This study financially was supported and ethically approved by the vice chancellor of research of Mashhad University of Medical Sciences, Iran. As screening for hemoglobin disorders, we performed hemoglobin electrophoresis (by Helena instrument, France) and complete blood count (CBC) (by Sysmex K-21, Japan) for all patients referred to our laboratory from pediatric, hematology and internal wards as well as the premarital genetic counseling clinic of Imam Reza teaching hospital (the biggest hospital in Mashhad, Khorasan province located in the Northeast of Iran) from 2004 to 2009. Subjects with a history of blood transfusion during 3 past months before admission were excluded from the study. In this period of time, 6033 samples were analyzed.
Procedure: After obtaining a short medical history, 2 milliliters blood was taken (using ethylenediaminetetraacetic acid (EDTA- K2) as anticoagulant) and $\mathrm{CBC}$ and hemoglobin electrophoresis on cellulose acetate at alkaline $\mathrm{PH}$ were performed within 24 hours of sampling. Regarding the fact, cellulose acetate electrophoresis doesn't separate hemoglobin $(\mathrm{Hb}) \mathrm{S}, \mathrm{D}, \mathrm{G}$ and lepor as well as Hb A2, C, E and $\mathrm{O}$, so high performance liquid chromatography (HPLC) was used for separation of these hemoglobins. ${ }^{2}$ We also perform sickling test for the confirmation of $\mathrm{Hb} \mathrm{S}$. $\mathrm{Hb} \mathrm{F}$ was confirmed by alkaline denaturation test and borderline $\mathrm{Hb} \mathrm{A} 2$ results (3.3\%-3.7\%) were rechecked by column chromatography. In case of suspicion to a $\mathrm{Hb} \mathrm{H}$ band in electrophoresis, supra-vital staining of blood with brilliant cresyl blue was done for evaluation of $\mathrm{He}$ moglobin $\mathrm{H}$ inclusions.

In cases over 2 years old, $\mathrm{Hb} \mathrm{A}>97 \%, \mathrm{Hb} \mathrm{F}<2-$ $3 \%$ and $\mathrm{Hb} \mathrm{A} 2<3.5 \%$ were considered normal. $\mathrm{B}$ thalassemia major ( $B^{0}$-Thalassemia) was defined as a $\mathrm{Hb} \mathrm{F}$ above $95 \%$ and $\mathrm{Hb} \mathrm{A} 2$ for the rest (with no $\mathrm{Hb} \mathrm{A})$; thalassemia intermedia to major $\left(\beta^{+}\right.$-Thalassemia) was defined as anemia with $30-95 \% \mathrm{Hb} \mathrm{F}$, and the presence of $\mathrm{Hb} \mathrm{A}(\mathrm{Hb} \mathrm{A} 2$ may or may not be increased) and finally, $\beta$-thalassemia minor ( $\mathrm{He}-$ terozygous state) was defined as $\mathrm{Hb} \mathrm{A} 2>3.5 \%$, occasionally with slightly increased $\mathrm{Hb} \mathrm{F}(1-3 \%)$ accompanied by characteristically elevated RBC, decreased MCV and MCH and usually normal $\operatorname{MCHC}(2,5)$.

Heterozygous $\delta \beta^{0}$-thalassemia was characterized as $5-20 \% \mathrm{Hb} \mathrm{F}$, with or without decreased $\mathrm{Hb} \mathrm{A} 2$ and the remainder $\mathrm{Hb} \mathrm{A}$ with heterogenous pattern of $\mathrm{HbF}$ in acid elution test along with thalssemia phenotype in CBC. Heterozygous hereditary persistence of fetal hemoglobin (HPFH) was characterized as $15-30 \% \mathrm{Hb} F$ with homogenous pattern of $\mathrm{HbF}$ in acid elution test, $\mathrm{Hb} \mathrm{A} 2<2.1 \%$ with no significant hematologic abnormalities in CBC. Heterozygous $\mathrm{Hb}$ Lepor was diagnosed as $\mathrm{Hb}$ Lepor of about $10 \%$, low Hb A2 and high $\mathrm{Hb} \mathrm{F}(2-3 \%)$.

Sickle cell disease ( $\mathrm{Hb} \mathrm{SS}$ ) was determined as over $80 \% \mathrm{Hb} \mathrm{S}, 1-20 \% \mathrm{Hb}$ F, 2-4.5\% $\mathrm{Hb} \mathrm{A} 2$ and no $\mathrm{Hb}$ A and sickle cell trait ( $\mathrm{Hb} \mathrm{AS}$ ) as over $50 \% \mathrm{Hb} \mathrm{A}$, $35-45 \% \mathrm{Hb} \mathrm{S}$ and up to $4.5 \% \mathrm{Hb} \mathrm{A2}$. Hb D was also characterized with similar hemoglobin pattern. $\mathrm{Hb} \mathrm{S} / \mathbb{B}^{+}$-Thalassemia was diagnosed by $\mathrm{Hb} \mathrm{S}$ was 


\begin{tabular}{|c|c|c|c|}
\hline Thal syndroms & $\%(n)$ & Hemoglobinopathies & $\%(n)$ \\
\hline B-Thal (heterozygous) & $19.44(1173)$ & $\mathrm{Hb} \mathrm{D}$ disease & $0.17(10)$ \\
\hline$\delta \beta^{0}$-thal (heterozygous) & $0.18(11)$ & $\mathrm{Hb} D$ trait & $1.46(88)$ \\
\hline Hb Lepor (heterozygous) & $0.03(2)$ & $\mathrm{Hb} \mathrm{S}$ disease & $0.13(8)$ \\
\hline Thal major & $0.23(14)$ & $\mathrm{Hb} S$ trait & $0.25(15)$ \\
\hline Thal intermedia to major & $0.25(15)$ & $\mathrm{Hb} \mathrm{S} / B^{+}$-thal & $0.02(1)$ \\
\hline HPFH (heterozygous) & $0.1(6)$ & $\mathrm{Hb} \mathrm{D} / B^{+}$-thal & $0.02(1)$ \\
\hline $\mathrm{Hb} \mathrm{H}$ & $0.1(6)$ & $\mathrm{Hb} \mathrm{C}, \mathrm{E}$ or $\mathrm{O}$ trait & $0.07(4)$ \\
\hline
\end{tabular}

over $50 \%, \mathrm{Hb} F \mathrm{~F}-20 \%, \mathrm{Hb} \mathrm{A} 15-30 \%$ and $\mathrm{Hb} \mathrm{A} 2$ $4-6 \%$ with mild hypochrom microcytic anemia. Similar criteria were considered for diagnosis of $\mathrm{Hb}$ $\mathrm{D} / \mathrm{B}^{+}$-Thalassemia. ${ }^{2}$

Descriptive statistics were computed by SPSS software (version 11.5).

\section{RESULTS}

We evaluated 6033 individuals (including 42\% males and $58 \%$ females) with age range of 1-88 years and mean of $26( \pm 1.5)$ years. Normal electrophoretic patterns were observed in $77.55 \%$ (4679 cases) and abnormal patterns in $22.44 \%$ (1354 cases). The frequency of thalassemias (and related disorders) was $20.29 \%$ and hemoglobinopathies was $2.15 \%$. The most common hemoglobin disorders, in order of frequencies, were $B$-thalassemia minor (19.44\%), Hb D (1.63\%), Hb S (0.38\%), thalassemia intermedia to major $(0.24 \%)$ and thalassemia major $(0.23 \%)$ (Table 1$)$. Among the hemoglobin disorders, thalassemias and related disorders and hemoglobinopathies included $90.5 \%$ and $9.5 \%$ of cases, respectively. Among hemoglobinopaties (127 cases), the frequencies of disorders were as follow: $\mathrm{Hb} \mathrm{D}(78 \%), \mathrm{Hb} \mathrm{S}(18.9 \%)$ and $\mathrm{Hb} \mathrm{C}, \mathrm{E}$ or $\mathrm{O}(3.1 \%)$.

\section{DISCUSSION}

The frequency of hemoglobin disorders varies noticeably with race and geographic area. The worldwide distribution of these disorders especially $\mathrm{Hb} \mathrm{S}$ are attributed to the distribution of malaria and possible resistance to malaria by heterozygous state. More common hemoglobin variants $(\mathrm{Hb} \mathrm{S}, \mathrm{Hb} \mathrm{C}$, $\mathrm{Hb}$ E, and $\mathrm{Hb} \mathrm{D}$ ) affect millions of people worldwide. $\mathrm{Hb} \mathrm{S}$ is more common in African population; Overall prevalence of $\mathrm{Hb} \mathrm{S}$ and $\mathrm{Hb} \mathrm{C}$ trait in African Americans are about $8 \%$ and $3 \%$, respectively. Probably, $\mathrm{Hb} \mathrm{E}$ is the most common hemoglobinopathy worldwide and the third most common in the United States after $\mathrm{Hb} \mathrm{S}$ and $\mathrm{Hb} \mathrm{C}$. $\mathrm{Hb} \mathrm{E}$ is most common in Southeast Asia especially Thailand with a prevalence of $50 \%$ in some areas of this country. ${ }^{6} \mathrm{Hb} \mathrm{D}$ has some variants; The most common variant is Hb D Punjab (an area in India) with a prevalence of about $3 \%$ in this area and another variant is $\mathrm{Hb} \mathrm{D}$ Iran. ${ }^{2}$

As shown in table 1, we found high frequencies of some hemoglobinopathies in our population that should be considered in the national screening program. We detected some differences in the frequencies of hemoglobinopathies compared with other reports so that the most common hemoglobinopathies in our study in order of frequencies were $\mathrm{Hb}$ $\mathrm{D}, \mathrm{Hb} \mathrm{S}$ and $\mathrm{Hb} \mathrm{C}, \mathrm{E}$ or $\mathrm{O}$. We observed only rare cases (4 cases) of $\mathrm{Hb} \mathrm{C}$, E or O, but for some limitations we couldn't differentiated them. In a study by Ashtiani et al for determination of prevalence of hemoglobinopathies in the capital city of Iran (Tehran), similar results were obtained. ${ }^{4}$ in a study in Oman for evaluation of hemoglobin disorders on children under 5 years old, the following results were seen: sickle cell trait $6 \%$, ß-thalassaemia $2 \%$, $\mathrm{Hb} \mathrm{D} 0.6 \%, \mathrm{Hb}$ E $0.3 \%$ and $\mathrm{Hb} \mathrm{C} 0.02 \% .^{7}$ In this 
study (on different group of population in comparison to our study) the most common hemoglobin disorder was sickle cell trait. $\mathrm{Hb} \mathrm{S} / \mathrm{B}^{+}$-thalassemia is the third most common sickling disorder following $\mathrm{Hb} \mathrm{SS}$ and $\mathrm{Hb} \mathrm{SC}$ in African Americans but we detected only one such a case, probably due to a low frequency of $\mathrm{Hb} \mathrm{S}$ disorders in our geographic area.

Thalassemias occur predominantly in Mediterranean region, Africa and Asia. ${ }^{2} \beta$-thalassemia genes especially are frequent in Greece and Sardinia and _thalassemia genes in Southeast Asia. ${ }^{2.5}$ Approximately, $3 \%$ of world population carry $B$-thalassemia gene. ${ }^{5}$ In Iran, Thalassemia is more common in the north (Caspian Sea coast) and the south (Persian Gulf and Oman Sea coasts) areas. The overall prevalence is approximately 3 to 100 patients per 100,000 in different provinces. ${ }^{3}$ We also found high prevalence of $\beta$-thalassemia in our study. $\beta$-thalassemia major is the most common autosomal disorder in $\operatorname{Iran}^{8}$ and it is estimated that over 25000 cases of thalassemia major currently live in Iran. ${ }^{9-10}$ We also detected the significant numbers of thalassemia major and intermedia (table 1). In a study by Sachdev et al in India on 2600 cases for determination hemoglobin disorders, abnormal hemoglobins were seen in 327 cases $(12.5 \%)$ including 15 cases of $\beta$-thalassemia major, 16 cases of $\beta$-thalassemia intermedia, 232 cases of $\beta$-thalassemia trait (8.9\%) and 13 cases of $\mathrm{Hb}$ D Punjab and other disorders (HB S, Hb E, Hb D Iran, Hb Q, Hb Lepore) for the rest (11). Similar to our results, predominant abnormalities were $\mathrm{B}$-thalassemia trait and $\mathrm{Hb} \mathrm{D}$ in Sachdev et al report.

In premarital screening programs in Saudi Arabia, Turkey and Iraq (neighbor countries of Iran) prevalence of $\beta$-thalassemia trait has been reported $3.4 \%$, $2-2.8 \%$ and $3.7 \%$, respectively. ${ }^{12-15}$ Although in these researches the most common hemoglobin disorders were $B$-thalassemia trait, but lower frequencies of $B$-thalassemia trait in these studies in comparison with our study probably originate from different case selection criteria (some patients with general complaints are also included in our study). Marouf et al study on 2,386 samples of hemoglobin electrophoresis in a hospital in Kuwait showed that the most commonly diagnosed hemoglobin disorders were beta-thalassemia minor (14\%), sickle cell trait $(6 \%)$, sickle cell anemia $(0.9 \%), \mathrm{S} / ß^{0}$-thalasse- mia $(0.8 \%)$ and $\mathrm{S} / \mathrm{B}^{+}$-thalassemia $(0.8 \%) \cdot{ }^{16} \mathrm{In}$ this study, similar to ours, hemoglobin electrophoresis were abnormal in $23.5 \%$ and the most common disorder was $B$-thalassemia minor, but the most common hemoglobinopathy was $\mathrm{Hb} \mathrm{S}$ and they identified only one case of Hb D Punjab. HPHF is found in about $0.1 \%$ of African Americans. ${ }^{2}$ We only characterized a few cases of HPHF and $\delta \beta^{\circ}$-thalassemia (heterozygous) in our research.

Hemoglobin $\mathrm{H}$ disease is more common in Southeast Asia, but it is also observed in Mediterranean and middle east area; and it is very rare in black people. ${ }^{2.5}$ We diagnosed rare cases of hemoglobin $\mathrm{H}$ in this study. Silent carrier and $\beta$ - thalassemia trait don't show any abnormalities in hemoglobin electrophoresis. Therefore, we couldn't diagnose these disorders.

Based on the fact that consanguineous marriages are common in Iran and premarital screening is being carried out for thalassemia; we also suggest that at least in these kinds of marriages, premarital screening of hemoglobin variants especially $\mathrm{Hb} \mathrm{S}$ and $\mathrm{Hb} \mathrm{D}$ being considered in the preventive program. Respecting our limitations, we couldn't differentiate $\mathrm{Hb} \mathrm{C}, \mathrm{E}$ or $\mathrm{O}$ from each other. This was also true for $\mathrm{Hb} \mathrm{D}$ variants, and diagnosis of B-thalassemia traits merely based on electrophoresis was impossible.

To conclude, hemoglobin disorders were a common problem in this population as abnormal results in electrophoresis were observed in $22.44 \%$ of individuals. The most common disorders were beta-thalassemia minor, thlassemia intermedia and major, $\mathrm{Hb} \mathrm{D}$, and $\mathrm{Hb} \mathrm{S}$. These results show the importance of the premarital screening program for hemoglobin disorders especially for thalassemias and some hemoglobinopathies.

\section{Acknowledgments}

This study was the results of a student's thesis financially supported by the vice chancellor of research of Mashhad University of Medical Sciences. We appreciate Dr. Ismaili for the Statistical advices and Mrs. Jalilli and Mrs. Marjani for performing laboratory tests. The authors also wish to thank Dr. Ramin Sadeghi and Dr. Ghasemi for revising the manuscript. 
This study was financially supported by the vice chancellor of research of Mashhad University of Medical Sciences

\section{REFERENCES}

1. Michael Angastiniotis BM. Global Epidemiology of Hemoglobin Disorders. Annals of the New York Academy of Sciences. 1998;850 (COOLEY'S Anemia: Seventh Symposium): 251-69.

2. Eleghentany MT, Banki K. Erythrocytic disorders. In: Mcpherson RA, Pincus MR, editors. Henry's Clinical diagnosis and management by laboratory methods. 21th ed: Saunders Elsevier, 2007: 519-32.

3. Abolghasemi H. Thalassemia in Iran - Epidemiology, prevention, and management. J Pediatr Hematol Oncol 29: 233-238, 2007.

4. Ashtiani MT, Monajemzadeh M, Sina AH, et al. Prevalence of haemoglobinopathies in 34,030 healthy adults in Tehran, Iran. J Clin Pathol 62: 924-925, 2009.

5. Lukens JN. The thalassemia and related disorders: quantitative disorders of hemoglobin synthesis. In: lee G, Lukens J, Greer J, Foerster J, Paraskevas F, Rodgers F, editors. Wintrob's clinical hematology. 10 ed. Philadelphia: Lipincott Williams and Wilkin, 1999: 14051435.

6. Lukens J. Abnormal hemoglobines: General principles. In: Greer J, Foerster J, Lukens J, Rodgers G, Paraskevas F, Glader B, editors. Wintrob's clinical hematology. 11 ed. Philadelphia: Lipincott Williams and Wilkins, 2004: 1247-1260.

7. Al-Riyami A, Ebrahim GJ. Genetic Blood Disorders Survey in the Sultanate of Oman. J Trop Pediatr 49 Suppl 1:11-20, 2003.

8. Khorasani G, Kosaryan M, Vahidshahi K, et al. Results of the national program for prevention of beta-thalassemia major in the Iranian Province of Mazandaran. Hemoglobin 32: 263-271, 2008.

9. Keramati MR, Maybodi NT. The effect of Iron Deficiency Anemia (IDA) on the HbA2 level and comparison of hematologic values between IDA and thalassemia minor. UHOD 17: 151-156, 2007.

10. Karimi M, Jamalian N, Yarmohammadi $\mathrm{H}$, et al. Premarital screening for beta-thalassaemia in Southern Iran: options for improving the programme. J Med Screen 14: 62-66, 2007.

11. Sachdev R, Dam AR, Tyagi G. Detection of Hb variants and hemoglobinopathies in Indian population using HPLC: Report of 2600 cases. Indian J Pathol Microbiol 53: 57-62, 2010.

12. Al-Suliman A. Prevalence of beta-thalassemia trait in premarital screening in Al-Hassa, Saudi Arabia. Ann Saudi Med 26: 14-16, 2006.
13. Guler E, Caliskan U, UcarAlbayrak C, Karacan M. Prevalence of beta-thalassemia and sickle cell anemia trait in premarital screening in Konya urban area, Turkey. J Pediatr Hematol Oncol 29: 783-785, 2007.

14. Guler E, Garipardic M, Dalkiran T, Davutoglu M. Premarital screening test results for beta-thalassemia and sickle cell anemia trait in east mediterranean region of Turkey. J Pediatr Hematol Oncol 29: 783-785, 2007.

15. Al-Allawi NA, Al-Dousky AA. Frequency of haemoglobinopathies at premarital health screening in Dohuk, Iraq: implications for a regional prevention programme. East Mediterr Health J 16: 381-385, 2010.

16. Marouf R, D'Souza T M, Adekile AD. Hemoglobin electrophoresis and hemoglobinopathies in Kuwait. Med Princ Pract 11: 38-41, 2002.

\section{Correspondence}

Mohammad Hadi Sadeghian

Cancer Molecular Pathology Research Center

Ghaem Hospital, Faculty of Medicine

Mashhad University of Medical Sciences

Mashhad / IRAN

Tel: +98 5118012584

Fax: +98 5118591057

e-mail: sadeghianmh@mums.ac.ir 